\title{
Citizenship: \\ Feminist Perspectives
}




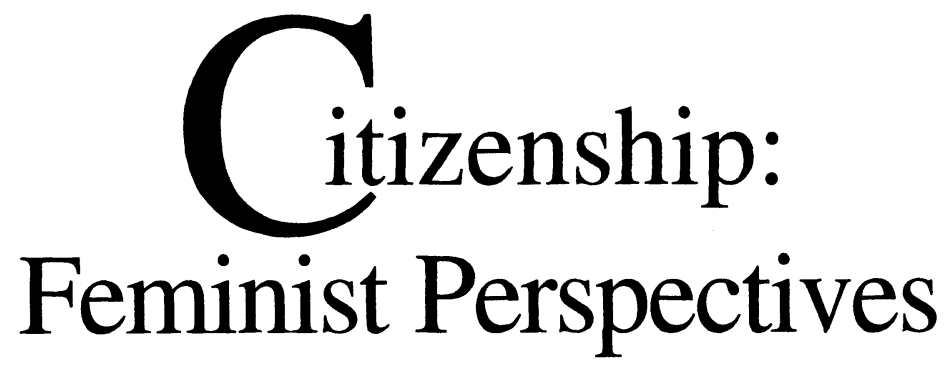

Ruth Lister

Consultant Editor: Jo Campling 


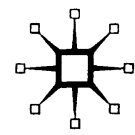

(C) Ruth Lister 1997

All rights reserved. No reproduction, copy or transmission of this publication may be made without written permission.

No paragraph of this publication may be reproduced, copied or transmitted save with written permission or in accordance with the provisions of the Copyright, Designs and Patents Act 1988, or under the terms of any licence permitting limited copying issued by the Copyright Licensing Agency, 90 Tottenham Court Road, London W1T 4LP.

Any person who does any unauthorised act in relation to this publication may be liable to criminal prosecution and civil claims for damages.

The author has asserted her right to be identified as the author of this work in accordance with the Copyright, Designs and Patents Act 1988.

Published by

PALGRAVE

Houndmills, Basingstoke, Hampshire RG21 6XS and 175 Fifth Avenue, New York, N.Y. 10010

Companies and representatives throughout the world

PALGRAVE is the new global academic imprint of St. Martin's Press LLC Scholarly and Reference Division and Palgrave Publishers Ltd (formerly Macmillan Press Ltd).

ISBN 978-0-333-53488-5 ISBN 978-1-349-26209-0 (eBook)

DOI 10.1007/978-1-349-26209-0

This book is printed on paper suitable for recycling and made from fully managed and sustained forest sources.

A catalogue record for this book is available from the British Library.

Editing and origination by Aardvark Editorial, Mendham, Suffolk

$\begin{array}{lllllllll}12 & 11 & 10 & 9 & 8 & 7 & 6 & 5 & 4\end{array}$

$\begin{array}{llllllllll}11 & 10 & 09 & 08 & 07 & 06 & 05 & 04 & 03 & 02\end{array}$ 
To my mother and the memory of my father; and also in memory of Hilary Arnott, 1944-94, a passionate opponent of exclusion and injustice. 


\section{Contents}

Preface

ix

List of abbreviations $\quad$ xii

Introduction: Why Citizenship? 1

A contested concept 3

Struggle and agency 4

The book: outline and disciplinary approach 7

Part I A Theoretical Framework 11

$\begin{array}{lll}\text { Chapter } 1 & 13\end{array}$

An essentially contested concept 14

Citizenship as rights $\quad 15$

Citizenship as general obligation $\quad 18$

Citizenship as political obligation 23

A critical synthesis 33

Conclusion 41

Chapter 2 Inclusion or Exclusion? 42

Inclusion/exclusion 43

The 'age of migration' 44

The nation-state under pressure $\quad 51$

Beyond the nation-state? 55

Shifting the boundaries of exclusion/inclusion $\quad 63$

Conclusion 65

Chapter 3 A Differentiated Universalism

Women's historical exclusion from citizenship $\quad 66$

Diversity, division and difference 72

The challenge of diversity and difference for citizenship 78

Living with the tension between the universal and particular $\quad 87$

Conclusion $\quad 90$

Chapter 4 Beyond Dichotomy 91

A gender-neutral or gender-differentiated
citizenship?

Beyond equality vs difference 94

Beyond an ethic of justice vs an ethic of care $\quad 100$

(In)dependence, autonomy and interdependence 105

Across the binary divides 115

$\begin{array}{ll}\text { Conclusion } & 116\end{array}$ 
Part II Across the Public-Private Divide: Policy, Practice and Politics

Chapter 5 Private-Public: the Barriers to Citizenship 119

Contesting the public-private divide

Autonomy undermined or promoted at the public-private intersection

The sexual division of labour, responsibility and time

The economic key to women's citizenship

Conclusion

Chapter 6 Women's Political Citizenship: Different and Equal

The masculine sphere of formal politics $\quad 146$

The feminine sphere of informal politics $\quad 147$

A different politics?

A more inclusive formal politics

Conclusion: Towards a woman-friendly political citizenship

Chapter 7 Women's Social Citizenship: Earning and Caring

Women as actors on the political stage of the welfare state

The two sides of the welfare state for women's social citizenship

Gendered welfare regimes and the state

Who is a social citizen?

Shifting the sexual division of labour

The balance of public and private responsibility for care

Paid work as citizenship obligation:

the case of lone parents

Conclusion

Conclusion: Towards a Feminist Theory and

Praxis of Citizenship

A feminist citizenship theory: building

blocks and threads

A feminist citizenship praxis $\quad 199$

Notes and References

Bibliography 


\section{Preface}

My approach to the question of citizenship reflects, in part, my own background in campaigning politics. The first 16 years of my working life were spent with the Child Poverty Action Group, a leading UK charity which works for the eradication of child and family poverty. In a book I subsequently wrote to mark CPAG's 25th anniversary, I noted that 'looking back we find that citizenship was one of the ideals that inspired the Group's early development. Although it did not emerge again as an explicit theme until the mid1980s, much of CPAG's work can be understood as a contribution to the wider struggle to extend full and genuine citizenship rights to those excluded by poverty' (1990a, p. 1). During some of that period I was also involved in the Women's Liberation Campaign for Financial and Legal Independence which focused mainly on the treatment of women in the social security and tax systems, 'in rebellion against women's partial citizenship' (Rowbotham, 1989, p. 148). It was through that campaign that I came to identify myself as a feminist, an identity that for me still holds good even though we are supposed to be living in 'post-feminist' times.

At about the time that I moved into higher education, in 1987, the language of citizenship re-emerged on the political and academic agenda. Having been invited to give the 1989 Eleanor Rathbone Memorial Lecture, I was struck by how Eleanor Rathbone in The Disinherited Family (republished 1986), together with some of her contemporaries, drew on the language of citizenship to make the case for the endowment of motherhood between the wars. Their arguments were still relevant to today's campaigns in defence of child benefit, the 'granddaughter' of the demand for the endowment of motherhood, and for women's financial independence. Furthermore, their gendered understanding of the concept of citizenship stood in contrast to the gender-blind, and therefore gender-biased, way in which it was being used by politicians in the late 1980s.

This led me to start asking a number of questions about women's role as citizens; about the limitations placed upon our rights as citizens and the constraints placed upon our ability to fulfil some of the 
obligations of citizenship. Those questions brought me eventually to this book. On the way I have developed my own understanding around these questions in three main ways. First, I have been able to pursue at a more theoretical level issues that previously I had approached primarily from the stance of an activist. From the new vantage point that this gives me, I blush slightly at the theoretical naivety of some of my writing then. Nevertheless, I would argue that our theoretical understanding of citizenship needs to be grounded in an appreciation of its practical and policy implications.

Second, at both a theoretical and political level, I have become more aware of the limitations of a gender analysis that suppresses the differences within the gender categories. This, in turn, has meant a greater consciousness of the, relatively privileged, standpoint from which I write: that of a Western, White, middle-class, heterosexual, non-disabled, childless, woman. (White and Black are capitalised to denote they are used as political categories.) In developing this feminist account of citizenship, I have tried on the one hand not to write as if from some universal woman's standpoint and on the other not to appropriate the voice of 'other' groups of women. In negotiating this difficult path, I have benefited from the work of other feminist authors such as Kathleen B. Jones (1993); Anna Yeatman (1993); and my colleagues Sue Wilkinson and Celia Kitzinger (1996). Similarly, in writing a piece of work that combines theory and policy, I have used examples from a range of countries to illuminate both similarities and differences, but am conscious of the dangers of superficial over-generalisation. It is for my readers to assess whether I have avoided such pitfalls.

Finally, my own perception of some of the practical manifestations of citizenship has shifted. In particular, I have become more conscious of the ways in which even, indeed in particular, some of the most disadvantaged women act as citizens and are not simply passive in their exclusion from the full panoply of citizenship rights. I have been helped here through my work with Peter Beresford of the Open Services Project looking at how people in poverty can exercise a voice in anti-poverty campaigns and through my membership of the independent Opsahl Commission into the future of Northern Ireland. The evidence given to the Commission by women's groups from working-class areas of Belfast provided an inspiring example of how women's active citizenship can flourish against all the odds.

The many people, including members of various research networks and contributors to conferences, whose ideas have helped 
me directly or indirectly on the long path from when the book was first conceived are too numerous to mention individually but a collective thank you is in order. There are nevertheless a number of people and organisations to whom individual thanks are due. First is my editor, Jo Campling, for her patience and her continued faith in the project despite my repeated failure to deliver. Second, I was lucky to have two committed research assistants at different stages of the project: Valerie Bryson and Parul Desai, whose contribution was invaluable. Valerie Bryson was funded by the Joseph Rowntree Foundation; and a Nuffield Foundation Social Science Research Fellowship enabled me to concentrate on writing the book for a whole academic year. I am most grateful to both Trusts. My heartfelt thanks go to Valerie Bryson again, along with Jane Lewis and Jim Kincaid who read the draft manuscript, and to Fiona Williams and Desmond King, who each read a couple of chapters. Anne Showstack Sassoon, who reviewed the manuscript for Macmillan, provided help beyond the call of duty. In each case, their comments have helped enormously in improving on the first draft; remaining weaknesses are of course my own responsibility. I am grateful to Vivian Dhaliwal for help with tidying up the bibliography and to Brian Negus for assistance in technical emergencies. Finally, I thank my closest friends, in particular J., for your loving support and tolerance, especially during those months when my anxiety levels were highest and my obsession with 'the book' was at its most tiresome. 


\section{List of abbreviations}

ANC African National Congress

CI Citizen's Income

CPAG Child Poverty Action Group

DEG Department of Employment Group

DSS Department of Social Security

EAPN European Anti-Poverty Network

EC European Commission

EFTA European Free Trade Area

EU European Union

HMSO Her Majesty's Stationery Office

ICA Invalid Care Allowance

ILO International Labour Office

IMF International Monetary Fund

NGO Non-governmental organisation

OECD Organisation of Economic Co-operation and Development

TUC Trades Union Congress

UN United Nations

UNDP United Nations Development Programme 